\title{
Mineralogical, Chemical and Thermal Characterisations of AnCiEnt Mortars of THE CHURCh OF SANTA MARÍA DE IRACHE MONASTERy (NAVARRA, SPAIN)
}

\author{
C. Montoya, J. Lanas, M. Arandigoyen, P.J. García Casado and J.I. Alvarez * \\ Department of Chemistry, University of Navarra, 31080, Pamplona (Spain)
}

\begin{abstract}
Ancient mortars used in the construction of the church of Santa María de Irache monastery have been studied. With the aim to characterise their binder and aggregate fractions, a complete characterisation has been carried out including chemical (rapid analysis, soluble salts and trace elements), mineralogical (structural characterisation and X-ray diffraction, $\mathrm{XRD)}$ and thermal studies (simultaneous differential thermal and thermogravimetric analysis, TGA-DTA). Lime binder, lime with dolomite phases and mixed mortars (lime and gypsum) have been determined. The approximate original composition of these classes of mortars have been presented. Advice about the employment of repair materials in a restoration are given.

\section{Résumé}

On a étudié les mortiers employés à l'église du monastère de Santa María de Irache. On a réalisé une caractérisation complète à l’object de connaître le liant et l'agrégat, en utilisant l'analyse chimique (analyse rapide, sels solubles et éléments trace), l’analyse minéralogique (caractérisation structurale et diffractométrie des rayons $\mathrm{X}, \mathrm{DRX}$ ) et des études thermiques (analyse thermique différentielle et thermogravimétrique ATD-ATG). On a établi l'utilisation de mortiers à la chaux aérienne, à la chaux aérienne avec de la dolomite, et de mortiers mixtes (chaux et plâtre). On présente la composition originale de ces types de mortiers. On donne des recommandations pour leur usage dans la restauration du monument.

*Corresponding author. Tel.: +00-34-948-425600; Fax: +00-34-948-425649

E-mail address: jalvarez@unav.es

\section{Introduction}


The restoration works of the historic monuments are of great importance today. The knowledge about the ancient raw materials and their technical process and chemical changes is essential for the repair works. The use of materials more chemically and mechanically compatible with the ancient masonry than modern cement mortars is very desirable [1-2]. The aim of this work is to study and characterise the ancient mortars used in the church of Santa María de Irache, in the southwest of Navarra (Spain).

The church dates from the $12^{\text {th }}$ century. Both the apse and the transept are in the Romanesque style. The naves are in the Cistercian style.

A preliminary grouping of different classes of the mortars has been realised by using the methods established in some previous studies [3-5]: mineralogical study (using XRD) and rapid chemical analysis. After the establishment of the constituent types of mortars, a complete study, with the purpose of characterising the materials and their origin, has been carried out. This was followed by different analyses: chemical (main components, trace elements, soluble salts); grain size distribution (aggregate granulometric fractions); and also thermal studies.

The approximate indications of the original composition of the raw material mixtures are presented. Advice in order to establish procedures for the employment of new materials in the process of restoration have been also given.

\section{Material and methods}

The sampling procedure for mortars has been carried out taking a part of the mortars with a chisel and throwing away the external portion of the joints, with the aim of obtaining nonaltered material.

A total of 51 mortar samples were studied, belonging to different areas (Gospel lateral nave: MA, MB and MC zones of sampling; dome area: zone C; Epistle lateral nave: E, EI, EE and 
ED zones; portico area: zone P) (Fig. 1). At least three samples of each architectural zone were taken to assure representative results.

X-ray diffraction analysis was undertaken using a Bruker D8 Advance diffractometer (Karlsruhe, Germany), according to the diffraction powder method, with a $\mathrm{CuK}_{\alpha 1}$ radiation and 0.02 increment and 1 s/step, sweep 2 to 90, $2 \theta$.

The complete sample (binder and aggregate) ground in an agate mortar is dried until constant weight in a heater at $105^{\circ} \mathrm{C}$ and then $1 \mathrm{~g}$ of sample is taken for its subsequent analysis. The rapid approximate chemical study was carried out after attack with hot $\mathrm{HCl}$ 1:5 volume ratio (2 M) [4], followed by a titration with ethylenediaminetetraacetic acid (EDTA) (using murexide and eBT (eriochrome black $\mathrm{T}$ ) as indicators) in order to determine calcium and magnesium concentrations. To establish the $\mathrm{CO}_{2}$ content, a calcimeter was used. The chemical analysis of the main components in the complete samples was carried out after an alkaline fusion followed by traditional chemical methods [6-7]: calcium and magnesium contents as previously mentioned; sodium and potassium levels were determined by flame atomic emission spectroscopy (Perkin Elmer 460, Überlingen, Germany); $\mathrm{R}_{2} \mathrm{O}_{3}$ (Fe, $\mathrm{Al}$ and $\mathrm{Ti}$ oxides) was determined by gravimetry (precipitation in the solution and calcination); $\mathrm{SO}_{3}$ was evaluated by precipitation as $\mathrm{BaSO}_{4}$ with a $10 \% \mathrm{w} / \mathrm{w} \mathrm{BaCl}_{2}$ solution; $\mathrm{SiO}_{2}$ was determined by weight difference of the sample (final-initial weight) after treatment in platinum crucible with $\mathrm{HF}(40 \% \mathrm{w} / \mathrm{w})$ and a few drops of $\mathrm{H}_{2} \mathrm{SO}_{4}$. The trace elements and their relative concentration have been determined using ICP-AES (Inductively coupled plasma atomic emission spectrometry, Jobin Ybon JY 38 S Plus Sequential, Instruments S.A., France), after previous alkaline digestion of the complete mortar sample. Anions were determined by ionic chromatography (HPLC Waters with conductivity detector Water 432, Milford, USA) after extraction with deionized water. The thermal analyser used was a simultaneous sDTA-TGA 
851 Mettler Toledo (Schwerzenbach, Switzerland) using alumina crucibles, at $20^{\circ} \mathrm{C} \cdot \mathrm{min}^{-1}$ heating rate under static air atmosphere.

\section{Results and discussion}

\subsection{Classification of the mortars}

\subsubsection{Mineralogical study}

The mean results of the mineralogical study using semi-quantitative XRD are reflected in Table 1. In the Gospel lateral nave (MA, MB, MC), dome area (C), Epistle lateral nave (EI) and portico area (P), lime mortar was established to be the predominant mortar type. Hexagonal calcite appears as the prevailing phase in all of the samples, and $\alpha$-quartz is the second mineralogical phase. In these samples, some phases of clay minerals have been observed, as well as albite and sanidine. The quantities of hydraulic phases found in the studied samples are very scarce. Such a very high burning point (probably $>850^{\circ} \mathrm{C}$ ) in the limestone materials implies that these compounds detected through XRD could only originate from aggregate added "a posteriori” or an intentional addition, since at high temperatures most of the compounds of the clay phase lose their crystalline structure [8]. The minuscule quantity present excludes intentional addition; therefore, it is probable that the clays present come from the added siliceous aggregate [9-11].

In the ES and EE zones, gypsum phases $\left(\mathrm{CaSO}_{4} \cdot 2 \mathrm{H}_{2} \mathrm{O}\right)$ have also been observed in most of the samples, in percentages between 5-20\%. The origin of this gypsum can be debatable: it could be added as an additive with different functions [12-13]. Alternatively, it could be evidence of a sulphatation. According to some factors (monument exposure and low concentration of some atmospheric pollutants), the first hypothesis is more probable. In any case, the temperature used in the gypsum production did not exceed around $300^{\circ}-500^{\circ} \mathrm{C}$, as irreversible anhydrite $\left(\beta-\mathrm{CaSO}_{4}\right)$ was not detected [13-14]. 
Table 1. Average results of x-ray diffraction of different zones.

\begin{tabular}{|c|c|c|c|c|c|c|}
\hline Zones & $\begin{array}{c}\text { a-quartz } \\
\left(\mathrm{SiO}_{2}\right) \\
\text { ICDD 85-798 }\end{array}$ & $\begin{array}{c}\text { Calcite } \\
\left(\mathrm{CaCO}_{3}\right) \\
\text { ICDD 05-0586 }\end{array}$ & $\begin{array}{c}\text { Gypsum } \\
\left(\mathrm{CaSO}_{4} \cdot 2 \mathrm{H}_{2} \mathrm{O}\right) \\
\mathrm{ICDD} 21-0816\end{array}$ & $\begin{array}{c}\text { Anhydrite } \\
\left(\gamma-\mathrm{CaSO}_{4}\right) \\
\text { ICDD 37-1496 }\end{array}$ & $\begin{array}{c}\text { Dolomite } \\
\left(\mathrm{CaMg}\left(\mathrm{CO}_{3}\right)_{2}\right) \\
\text { ICDD 36-0426 }\end{array}$ & $\begin{array}{c}\text { Complex } \\
\text { silicates }\end{array}$ \\
\hline Dome area (C) & $\mathrm{a}$ & $\mathrm{a}$ & - & - & - & $\mathrm{t}$ \\
\hline $\begin{array}{l}\text { Gospel lateral } \\
\text { (MA, MB, MC) }\end{array}$ & $\mathrm{a}$ & $\mathrm{a}$ & - & - & - & $\mathrm{t}$ \\
\hline $\begin{array}{c}\text { Epistle lateral } \\
\text { (E, EI, DE) }\end{array}$ & $\mathrm{b} / \mathrm{a}$ & $\mathrm{a}$ & - & - & $s / t$ & $\mathrm{t}$ \\
\hline Portico area (P) & $b$ & $\mathrm{a}$ & $\mathrm{t}$ & - & - & $\mathrm{t}$ \\
\hline Epistle nave (ES) & $\mathrm{b} / \mathrm{a}$ & $\mathrm{a}$ & s & - & - & $\mathrm{t}$ \\
\hline Epistle nave (EE) & $\mathrm{b} / \mathrm{a}$ & $\mathrm{a}$ & $\mathrm{s}$ & - & - & $\mathrm{t}$ \\
\hline
\end{tabular}

a: 40\%-75\%; b: 20\%-40\%; s: small amount (5\%-20\%); t: traces (<5\%);-: absent.

\subsubsection{Rapid chemical analysis and classification}

Results of the chemical analysis with hot $\mathrm{HCl}$ 1:5 volume ratio (2M) have allowed the grouping of the mortars. The outlier values were eliminated from the results via an aberrant test employing the Student’s test t, giving a 95\% confidence level [3-5,15].

Table 2 shows the average values for different large sampling areas, taking into account the XRD results, in order to put samples into groups according the presence of different mineralogical phases.

Table 2. Results of the rapid chemical analysis in original sample of dry mortar. Average values in percentages for the various sampling zones.

\begin{tabular}{|c|c|c|c|c|c|c|c|c|c|c|c|c|c|}
\hline \multirow{3}{*}{ Zones } & \multirow{3}{*}{$\mathbf{n}$} & \multirow{2}{*}{\multicolumn{3}{|c|}{$\begin{array}{l}\text { Insoluble Residue } \\
\text { (IR) }\end{array}$}} & \multicolumn{9}{|c|}{ Soluble Fraction (SF) } \\
\hline & & & & & \multicolumn{3}{|c|}{$\mathrm{CaCO}_{3}$} & \multicolumn{3}{|c|}{$\mathrm{CaSO}_{4} \cdot 2 \mathrm{H}_{2} \mathrm{O}$} & \multicolumn{3}{|c|}{$\begin{array}{c}\text { Other compounds } \\
\text { (OCSF) }\end{array}$} \\
\hline & & $\mathbf{X}$ & S.D. & C.V. & $\mathbf{X}$ & S.D. & C.V. & $\mathbf{X}$ & S.D. & C.V. & $\mathbf{X}$ & S.D. & C.V. \\
\hline C & 5 & 13.35 & 9.23 & 69.14 & 79.88 & 12.99 & 16.26 & & & & 6.77 & 4.31 & 63.66 \\
\hline $\begin{array}{l}\text { MA/MB/ } \\
\text { MC }\end{array}$ & 10 & 26.07 & 5.01 & 19.22 & 63.01 & 4.36 & 6.92 & & & & 10.94 & 4.56 & 41.68 \\
\hline E/EI/ED & 15 & 23.98 & 3.38 & 14.10 & 69.33 & 3.90 & 5.63 & & & & 6.68 & 2.21 & 33.08 \\
\hline $\mathbf{P}$ & 6 & 32.97 & 3.28 & 9.95 & 61.51 & 5.38 & 8.75 & & & & 5.52 & 2.53 & 45.83 \\
\hline ES & 9 & 20.56 & 1.20 & 5.84 & 62.46 & 7.78 & 12.46 & 11.09 & 4.07 & 36.70 & 16.98 & 7.54 & 44.41 \\
\hline EE & 6 & 27.26 & 4.99 & 18.31 & 64.30 & 5.51 & 8.57 & 4.16 & 2.36 & 56.73 & 8.43 & 4.32 & 51.25 \\
\hline
\end{tabular}

n: population; X: average; S.D.: standard deviation; C.V.: coefficient of variation 
In order to establish the comparison between the chemical composition of the zones, a nonparametric statistical test has been used. The Kruskal-Wallis test has shown significant differences in the percentages of IR (insoluble residue) $(\mathrm{p}=0.001), \mathrm{CaCO}_{3}(\mathrm{p}=0.003)$ and OCSF (other compounds of soluble fraction) $(\mathrm{p}=0.001)$ between all the zones. Two-by-two comparisons were carried out using the U Mann-Whitney test: significant differences in $\% \mathrm{CaCO}_{3}$ and \%OCSF between EE, ES zones (with gypsum phases in their composition) and the other zones have been checked.

Through the application of these discrimination standards, three different classes of lime mortars can be grouped into various architectural zones: MC1 (Dome area: C), MC2 (Gospel lateral nave: MA, MB and MC), and MC4 (Portico area: P). A lime mortar with small percentage of dolomite has been determined for Epistle lateral nave E, EI and ED (MC3 class). A mixed mortar with lime and gypsum and with silica aggregate has been established for zones of the Epistle nave ES and EE: MY1 and MY2 classes, respectively.

In order to carry out the complete characterisation, a representative sample of each class of mortar has been chosen. The chosen samples appear in the Table 3 (Table 2 collects the mean values of each class). The criteria followed have been: the state of aggregation and structure, the available quantity and the representativity on the set. From now on, we refer to the class of samples or to the representative sample without distinction.

Table 3. Representative samples of each class of mortars. Values of soluble fraction $\left(\mathrm{CaCO}_{3}\right.$, $\mathrm{CaSO}_{4} \cdot 2 \mathrm{H}_{2} \mathrm{O}$ and other compounds of soluble fraction OCSF) and IR (percentages related to original dry mortar).

\begin{tabular}{|c|c|c|c|c|c|c|}
\hline $\begin{array}{c}\text { Representative sample } \\
\text { (Performed Class) }\end{array}$ & $\begin{array}{l}\text { C-15 } \\
(\mathrm{MC1}) \\
\end{array}$ & $\begin{array}{l}\text { MC-7 } \\
\text { (MC2) }\end{array}$ & $\begin{array}{l}\text { EI-37 } \\
\text { (MC3) }\end{array}$ & $\begin{array}{l}\text { P-48 } \\
\text { (MC4) } \\
\end{array}$ & $\begin{array}{l}\text { ES-22 } \\
\text { (MY1) }\end{array}$ & $\begin{array}{l}\text { EE-43 } \\
\text { (MY2) }\end{array}$ \\
\hline \multicolumn{7}{|l|}{ Soluble fraction (\%) } \\
\hline $\mathrm{CaCO}_{3}$ & 83.55 & 67.65 & 70.04 & 64.88 & 63.26 & 64.15 \\
\hline $\mathrm{CaSO}_{4} \cdot 2 \mathrm{H}_{2} \mathrm{O}$ & - & - & - & - & 10.69 & 7.85 \\
\hline $\begin{array}{l}\text { Other compounds } \\
\text { OCSF }\end{array}$ & 6.58 & 7.13 & 6.00 & 4.71 & 14.73 & 14.15 \\
\hline Insoluble residue (\%) & 9.87 & 25.23 & 23.96 & 30.41 & 22.01 & 21.70 \\
\hline
\end{tabular}




\subsection{Complete characterisation of representative samples}

\subsubsection{Chemical study}

Chemical composition: By using traditional chemical methods, a chemical analysis of the main components in complete mortar samples (binder and aggregate) has been carried out. The results are included in Table 4.

Table 4. Complete chemical analysis of the complete representative samples.

\begin{tabular}{|c|c|c|c|c|c|c|c|c|}
\hline $\begin{array}{l}\text { Representa- } \\
\text { tive sample }\end{array}$ & Loss $^{a}$ & $\begin{array}{c}\mathrm{SiO}_{2}{ }^{\mathrm{b}} \\
(\%)\end{array}$ & $\begin{array}{l}\mathrm{CaO} \\
(\%)\end{array}$ & $\begin{array}{c}\text { MgO } \\
(\%)\end{array}$ & $\begin{array}{c}\mathrm{R}_{2} \mathrm{O}_{3}{ }^{\mathrm{C}} \\
(\%)\end{array}$ & $\begin{array}{l}\mathrm{SO}_{3} \\
(\%)\end{array}$ & $\begin{array}{c}\mathrm{Na}_{2} \mathrm{O} \\
(\%)\end{array}$ & $\begin{array}{l}\mathrm{K}_{2} \mathrm{O} \\
(\%)\end{array}$ \\
\hline MC1 & 37.08 & 11.98 & 44.92 & 2.54 & 1.69 & 1.30 & 0.36 & 0.59 \\
\hline MC2 & 32.66 & 19.73 & 34.78 & 6.21 & 5.18 & 1.34 & 0.28 & 0.62 \\
\hline MC3 & 33.01 & 19.84 & 37.77 & 3.56 & 2.90 & 1.81 & 0.11 & 0.28 \\
\hline MC4 & 34.91 & 18.49 & 43.13 & 1.27 & 1.80 & 0.65 & 0.13 & 0.15 \\
\hline MY1 & 31.22 & 15.94 & 40.95 & 1.82 & 3.88 & 5.37 & 0.22 & 0.12 \\
\hline MY2 & 33.81 & 17.97 & 39.53 & 3.56 & 2.69 & 2.03 & 0.12 & 0.23 \\
\hline
\end{tabular}

Percentages related to original dry mortar.

${ }^{a}$ Loss indicates the loss due to calcination at $975-1000^{\circ} \mathrm{C}$.

${ }^{b}$ The percentages of $\mathrm{SiO}_{2}$ refers to the total silica in the sample.

${ }^{\mathrm{c}} \mathrm{R}_{2} \mathrm{O}_{3}$ expresses the percentage of $\mathrm{Fe}, \mathrm{Al}$ and $\mathrm{Ti}$ as oxides.

A good agreement between these results and the previous measurements (XRD and rapid chemical analysis) was obtained. Sample MC1 showed a high values of parameters related to the binder amount: $\mathrm{CaO}$ and calcination loss. In MC2 class, the highest percentage of $\mathrm{R}_{2} \mathrm{O}_{3}$ was determined. An outstanding presence of complex silicates may give an explanation of this fact. MC2 sample has also shown high values of MgO (6.21\%). According to this fact, the use of dolomitic limes could be proved, but XRD results did not show any dolomite phase. In order to clarify this situation, other techniques of characterisation were necessary. However in MC3 class the presence of dolomite has been established by XRD. A relatively high amount of $\mathrm{MgO}$ (3.56\%) was determined in this zone.

The low content in $\mathrm{Fe}$ and $\mathrm{Al}$-in spite of the analysis of the binder together with the aggregate - allows to check the small amount of hydraulic compounds. This fact could be also proved regarding the XRD results that not showed any hydraulic compound, and also the 
TGA-DTA results, as later will be considered, that not showed any weight loss between $200^{\circ}$ and $600^{\circ} \mathrm{C}$ (related with the water of hydraulic compounds). Therefore, it could indicate that mortars have aerial lime as binder.

Trace elements: An analysis of trace elements in the full mortar samples has been carried out. Figure 2 shows the graphs of trace metals. It has already been pointed out in previous papers that the chemical nature of the trace elements and their relative concentrations indicate the geological history of the mortar [16-17]. The critical study of these graphs indicates that there are not large differences in the composition of the trace metals analysed among the mortars of MC2, MC3 and MC4 classes. However, important differences between the aforementioned classes and MC1, MY1 and MY2 classes have been obtained.

Soluble salts: By using methods of determination of soluble salts, the risk of deterioration of building materials can be measured. In fact, high contents of soluble salts may permit their dissolving and crystallisation, which could disintegrate the mortar $[7,9,18]$. In this way, a measure of overall conductivity in representative samples was taken. Figure 3 shows the results referred to a suspension that contains $1 \mathrm{mg}$ of sample for $\mathrm{mL}$, expressed in $\mu \mathrm{S} . \mathrm{cm}^{-1}$.

Low conductivity values, with reference to the bibliographical data, were obtained $[7,9,19]$. Obviously, a scarce total salinity must be considered. Nevertheless, the MY1 class shows a more marked salinity.

Figure 3 also summarises the anion concentrations. Very low $\mathrm{Cl}^{-}$contents in comparison to some studies have been determined (0.67-2.27\%, [19]). Nitrate contents also show low values, although very low values for MC2 and MC4 classes have been obtained. Outstanding amounts of sulphate ion were determined in MC1, MY1 and MY2 classes. Regarding the XRD results, no significant gypsum phases in MC1 class was found. However, the sulphate ion contents in this class are considerable. Taking into account all the facts mentioned above, it is possible that MC1 class presents alkaline sulphates instead of calcium sulphates. The 
differences in solubility between alkaline sulphates (more soluble) and calcium sulphates (less soluble) would give an explanation, because alkaline sulphates could be better extracted with cold water than calcium sulphates. The previous chemical analysis results ( $\mathrm{Na}$ and $\mathrm{K}$ contents) shows an agreement with this hypothesis.

\subsubsection{Aggregate granulometric fractions}

The distribution characteristics of the grain size of the aggregate through a granulometric study have also been undertaken. They have configured the showed distributions (Fig. 4). The grading of the aggregate (after dissolution of the binding material with $\mathrm{HCl} 1: 1$ ) shows, as can be seen from the preceding graph, that for the fraction $<0.1 \mathrm{~mm}$ all the samples give high values, above 20\%. In MY2 and MC2 samples very high rejected percentages were observed for this fraction.

The fine sand fraction $(0.25-0.50 \mathrm{~mm})$ is in percentage terms the most important fraction of the aggregates analysed in MC1, MC3, MC4 and MY1 samples. In the other fractions (intermediate sand (1-1.6 mm) and coarse sand (2-4 mm)) only the MC3 mortar showed a remarkable percentage of the coarse fraction (23\%).

The grain size data showed a symmetric distribution for MC1 class around the range of 0.25mm (unimodal distribution) [20]. A bimodal distribution around 0.5 and $1.25 \mathrm{~mm}$ was established for MC4, and similar for MC2 and MY2 (around 0.1 and $1.25 \mathrm{~mm}$ ). For MC3 and MY1 classes, trimodal distributions were shown, around 0.1, 1.25 and $2 \mathrm{~mm}$ (MC3) and around 0.25, 1.25 and $2 \mathrm{~mm}$ (MY1).

In order to catalogue the grading distribution curves of the aggregates two statistical parameters were used: the median and the "sorting-index" (the quotient between the $3^{\text {rd }}$ and $1^{\text {st }}$ quartile expressed in $\mathrm{mm}$ ) [21]. The results are shown in the Table 5.

Table 5. Median and sorting-index.

\begin{tabular}{ccc}
\hline Representative sample & Median & $\mathbf{S}_{\mathbf{0}}$ (sorting-index) \\
\hline MC1 & 0.16 & 4.57
\end{tabular}




\begin{tabular}{lcc} 
MC2 & 0.12 & 5.37 \\
MC3 & 1.29 & 16.98 \\
MC4 & 0.25 & 11.75 \\
MY1 & 0.18 & 6.46 \\
MY2 & 0.10 & 4.47 \\
\hline
\end{tabular}

Via the value of the median we found that the MC1, MC2, MC4, MY1 and MY2 mortars have in their majority fine sand composition (median $<0.5 \mathrm{~mm}$ ). Only MC3 mortar showed mainly intermediate sands (from $0.5 \mathrm{~mm}$ to $1.6 \mathrm{~mm}$ ).

Otherwise, the $S_{o}$ indicated a badly distributed sand $\left(S_{o}>4.5\right)$ for all the classes. However, limit values were observed in MC1 and MY2 classes. Differences between the aggregates used in MC2 and MY2 classes, and the other classes could be established. It has to be considered that both median and $\mathrm{S}_{\mathrm{o}}$ must be interpreted with caution.

\subsubsection{Thermal studies}

Differential thermal and thermogravimetric analyses are suitable in order to establish characteristics of the ancient mortars: it is easy to detect the main components, the nature of the aggregate and other aspects, whit a small quantity of sample. The previously obtained results by means of other analytical techniques have been confirmed in the thermal studies carried out.

The MC1 class presents a DTA curve characterised by an important endothermic peak at $900^{\circ} \mathrm{C}$ (Fig. 5). This peak is related with the decarbonation of the calcite (Eq.1), and the weight loss associated has been originated by the $\mathrm{CO}_{2}(\mathrm{~g})$ evolution $[15,22]$ :

$$
\mathrm{CaCO}_{3} \rightarrow \mathrm{CaO}+\mathrm{CO}_{2}
$$

The onset temperature of the decarbonation peak of the $\mathrm{CaCO}_{3}\left(\sim 700^{\circ} \mathrm{C}\right)$ is too low for the temperature of the minimum $\left(\sim 900^{\circ} \mathrm{C}\right)$ [22]. Between $700^{\circ} \mathrm{C}$ and $850^{\circ} \mathrm{C}$, the DTA curve is partly erratic, with some little steps. These two facts could be due to the presence of small amounts of dolomite, $\mathrm{CaMg}\left(\mathrm{CO}_{3}\right)_{2}$. Dolomite decomposes in those temperature ranges [22]. 
This hypothesis would be supported by the percentage of MgO, relatively important, obtained in the chemical analysis of the sample. Although phases of dolomite have not been detected by $\mathrm{XRD}$, its presence is not completely dismissed: the poor crystallinity of the dolomite and/or its presence in small amounts could mask its detection by XRD [15,23].

A similar interpretation can be presented for the MC2 class, seeing in the DTA curve an endothermic peak without associated weight loss. This peak at $\sim 570^{\circ} \mathrm{C}$ can be related with the polymorfic transformation of the $\alpha$-quartz. The peak is small because the energy associated with this change is very small (Eq.2) [24].

$$
\alpha-\text { quartz } \rightarrow \beta-\text { quartz } \quad 573{ }^{\circ} \mathrm{C}(\text { Eq.2) }
$$

For the MC3 analysis (Fig. 6), also a point of inflection at $\sim 800^{\circ} \mathrm{C}$ (corresponding to a minimum in the differential thermogravimetric curve - DTG-) can be observed and related with the dolomite decomposition. This association is in agreement with other previous results from XRD and chemical analysis.

For the MY1 (Fig. 7) and MY2 classes, some endothermic peaks, with associated weight losses between $150^{\circ} \mathrm{C}$ and $200^{\circ} \mathrm{C}$, have been highlighted in the two samples. With the help of the DTG curve, an endothermic doublet at about $160^{\circ} \mathrm{C}$ and $180^{\circ} \mathrm{C}$ was observed. This doublet could be ascribed to the loss of water of crystallisation of the gypsum $\left(\mathrm{CaSO}_{4} \cdot 2 \mathrm{H}_{2} \mathrm{O}\right)$. The gypsum dehydration takes place in two next stages (Eq.3-4) [25]:

$$
\begin{array}{lr}
\mathrm{CaSO}_{4} \cdot 2 \mathrm{H}_{2} \mathrm{O} \rightarrow \mathrm{CaSO}_{4} \cdot 1 / 2 \mathrm{H}_{2} \mathrm{O}+\frac{3}{2} \mathrm{H}_{2} \mathrm{O} & 162{ }^{\circ} \mathrm{C} \text { (Eq.3) } \\
\mathrm{CaSO}_{4} \cdot 1 / 2 \mathrm{H}_{2} \mathrm{O} \rightarrow \mathrm{CaSO}_{4}+1 / 2 \mathrm{H}_{2} \mathrm{O} & 174{ }^{\circ} \mathrm{C} \text { (Eq.4) }
\end{array}
$$

All the previous results (XRD, chemical analysis and soluble salts determination) agree with the results of the thermal studies.

\section{Conclusions}


The mortars of the church of Santa María de Irache present aerial lime as main binder. However, an important variability in the mortar compositions has been observed. The classes MC1, MC2 and MC4 are aerial lime-based mortars with a silica aggregate. The class MC3 presents phases of dolomite with lime and the classes MY1 and MY2 are a mixed mortar (lime and dihydrated calcium sulphate - gypsum-). The nature of the aggregate in all of these samples turns out to be predominantly siliceous.

The calculation of the initial weight percentages of raw materials has given the values collected in Table 6 for each class of mortars. The simple formulas used to calculate these percentages are collected in some previous works $[5,15]$. These formulas are based on the correction of the weight increment taken place in the mortar during the lime carbonation [26] (Eq.5):

$$
\mathrm{Ca}(\mathrm{OH})_{2}+\mathrm{CO}_{2} \rightarrow \mathrm{CaCO}_{3}+\mathrm{H}_{2} \mathrm{O}
$$

For these calculations the results of $\mathrm{CaCO}_{3}$ contents determined by means of the TG analysis and the chemical analysis were used. A similar process could be described for the conversion of the $\mathrm{Mg}(\mathrm{OH})_{2}$ in dolomite. For the classes MY1 and MY2 of mortars the $\mathrm{CaSO}_{4} \cdot 2 \mathrm{H}_{2} \mathrm{O}$ appears as original component of the mixtures.

Table 6. Approximate original composition of the classes of mortars (weight percentages).

\begin{tabular}{ccccccc}
\hline Class & $\begin{array}{c}\mathbf{C a}(\mathbf{O H})_{2} \\
(\mathbf{\%})\end{array}$ & $\begin{array}{c}\text { Aggregate } \\
\mathbf{( \% )}\end{array}$ & $\begin{array}{c}\mathbf{M g}(\mathbf{O H})_{2} \\
\mathbf{( \% )}\end{array}$ & $\begin{array}{c}\mathbf{C a S O}_{\mathbf{4}} \mathbf{2} \mathbf{H}_{2} \mathbf{O} \\
\mathbf{( \% )}\end{array}$ & $\begin{array}{c}\text { Water of } \\
\text { constitution } \\
\mathbf{( \% )}\end{array}$ & $\begin{array}{c}\text { Weight } \\
\text { ratio } \\
\text { binder- } \\
\text { aggregate }\end{array}$ \\
\hline MC1 & 79.1 & 12.6 & - & - & 8.3 & 6.3 \\
MC2 & 61.0 & 30.6 & - & - & 8.4 & 2.0 \\
MC3 & 60.1 & 29.0 & 6.1 & - & 4.8 & 2.3 \\
MC4 & 57.8 & 36.6 & - & - & 5.6 & 1.6 \\
MY1 & 56.0 & 26.3 & - & 12.8 & 4.9 & 2.1 \\
MY2 & 57.0 & 26.0 & - & 9.4 & 7.6 & 2.2 \\
\hline
\end{tabular}


Except for the class MC1, with an excess of binder, the weight binder/aggregate relationships respond to normal quotients (between 0.5 and 2.5 approximately, according to the results from the literature [27-30].

The MC1 class shows a high amount of soluble sulphates, alkaline probably. Given the deterioration risk, the use for restoration of similar materials is not advisable. The deterioration could be caused by the sulphates dissolution in water or by their important expansive capacity.

On the distribution of the aggregate, no class is especially appropriate. The excess of fine sands is not adequate. In this way, it would suit to revise the distribution characteristics of the grain size in an eventual intervention in the monument.

The conjugated use of different analytical techniques for the characterisation of ancient mortars is very recommended. Specifically, the complementary employment of both studies XRD and thermal analysis can be highlighted. Both methods are very suitable for these studies.

On their employment in reconstruction, neither the relationship binder/aggregate of MC1 class, nor the presence of certain components of MY1 and MY2 (with gypsum, more soluble, with risk of deterioration) and MC3 (with phases of magnesium, with a setting slower) seem to be appropriate $[20,30,31]$. We incline for a mortar with a relationship binder/aggregate between those of the classes MC2 (relationship 2:1) and MC4 (relationship 1,6:1), and also we suggest the use of similar materials.

\section{References}

[1] Rodríguez-Navarro, C., Hansen, E., Ginell, W.S., 'Calcium Hydroxide Evolution upon Aging of Lime Putty’, J. Am. Ceram. Soc. 81 (11) (1998) 3032-3034.

[2] Moropoulou, A., Theodoraki, A., Bisbikou, K., Michailidis, M., 'Restoration synthesis of crushed brick mortars simulating Byzantine lime and material technologies in Crete', Mat. Res. Soc. Symp. Proc. 352 (1995) 759-767.

[3] Alvarez, J.I., Martín, A., García Casado, P.J., 'Methodology used in the characterisation of the mortars of Pamplona’s Cathedral (Spain)' «only available in French», in: J. Riederer 
(Ed.), 8th Congress International on Deterioration and Conservation of Stone, Berlin, 1996, 1457-1470.

[4] Alvarez, J.I., Martín, A., García Casado, P.J., Navarro, I., Zornoza, A., 'Methodology and validation of a hot hydrochloric acid attack for the characterisation of ancient mortars', Cem. Concr. Res. 29 (7) (1999) 1061-1065.

[5] Alvarez, J.I., Navarro, I., Martín, A., García Casado, P.J., 'A study of the ancient mortars in the north tower of Pamplona's San Cernin church', Cem. Concr. Res. 30 (2000) 1413-1419.

[6] Voïnovitch, I.A., 'Analyse des sols, roches et ciments' (Ed. Masson, Paris, 1988).

[7] Martín, A., 'Alteration tests for conservation in stone buildings of Cultural Heritage'(In Spanish), (Centro de Estudios Ramón Areces, Madrid, 1990).

[8] Kawiak, T., 'Gypsum mortars from a twelfth-century church in Wislica, Poland', Stud. Conserv. 36 (1991) 142-150.

[9] Blanco-Varela, M.T., Puertas, F., Macías, A., Palomo, A., 'Study of support romain mortars of Italica's mosaics’, in: J.Delgado Rodrigues, F. Henriques, F. Telmo Jeremias (Eds.), 7th International Congress on Deterioration and Conservation of Stone, Laboratório Nacional de Engenharia Civil, Lisbon, 1992, 1299-1305.

[10] Sarkar, S.L., 'Microstructural investigation of renaissance mortar from Montreal, Quebec, Canada', Cem. Concr. Res. 22 (1992) 1011-1018.

[11] Marchese, B., Garzillo, V., 'An investigation of the mosaics in the cathedral of Salerno: Part I. Characterisation of binding materials', Stud. Conserv. 28 (1983) 127-132.

[12] Martinet, G., Deloye, F. Golvin, J.C., 'Characterisation of the pharaonic mortars of Amon's Temple in Karnak', «only available in French» Bull. Liaison Lab. Ponts Chaussees 181 (1992) 39-45.

[13] Ashurst, J., 'Mortars, plasters and renders in conservation', (Ecclesiastical Architect's and Surveyors' Association, 1983, 16-18).

[14] De la Torre, M.J., Sebastián Pardo, E., Rodríguez-Navarro, C., García, M., Buendía, A., Moreno, Valverde Espinosa, I., 'A study of building materials used in the Alcazaba of Loja, Granada, Spain’ (In Spanish), in: E.M. Sebastián Pardo, I. Valverde Espinosa, U. Zezza (Eds.), III Congreso Internacional de Rehabilitación del Patrimonio Arquitectónico y Edificación, Granada (España), 1996, 221-225.

[15] Alvarez, J.I., Navarro, I., García Casado, P.J., 'Thermal, mineralogical and chemical studies of the mortars used in the cathedral of Pamplona (Spain)', Termochim. Acta 365 (2000) 177-187.

[16] De la Torre, M.J., Rodríguez, J., Sebastián, E.M., 'Geochemical characterisation of Hispanic-muslim mortars and concretes. Origin of the raw materials' (In Spanish), in: CEDEX (Ed.), IV Congreso de Geoquímica de España, Soria, 1991, 470-478.

[17] Bello, M.A., Martín, A., 'Microchemical characterisation of building stone from Seville Cathedral, Spain’, Archaeometry 34 (1) (1992) 21-29.

[18] Borges, C., Caetano, C., Costa Pessoa, J., Figueiredo, M.O., Lourenço, A., Malhoa, M., Gomes, T.P., Silva, J.P., Veiga, A. 'Monitoring the removal of soluble salts from ancient tiles by ion chromatography', J. Chromatogr. A 770 (1997) 195-201.

[19] Alessandrini, G., Bugini, R., Negrotti, R., Toniolo, L., 'Characterisation of plasters from the church of San Niccolò di Comelico (Belluno- Nothern Italy)', Eur. J. Mineral. 3 (1991) 619-627.

[20] Riccardi, M.P., Duminuco, P., Tomasi, C., Ferloni, P., 'Thermal, microscopic and X-ray diffraction studies on some mortars’, Termochim. Acta 321 (1998) 207-214. 
[21] Frizot, M., 'Mortiers et enduits peints antiques- étude technique et archéologique', in: Université de Dijon (Ed.), Centre de Recherches sur les techniques gréco-romains, 1975, 57-137.

[22] Webb, T.L., Krüger, J.E., 'Carbonates', in: R.C. Mackenzie (Ed.) 'Differential Thermal Analysis’, (Academic Press Inc., London, 1970, 303-341).

[23] Bruni, S., Cariati, F., Fermo, P., Pozzi, A., Toniolo, L., 'Characterisation of ancient magnesian mortars coming from northern Italy’, Termochim. Acta 321 (1998) 161-165.

[24] Newton, R.G., Sharp, J.H., 'The chemical composition of lime plasters', Cem. Concr. Res. 17 (1987) 77-80.

[25] Hatakeyama, T., Liu, Z., 'Handbook of Thermal Analysis', (John Wiley \& Sons Ltd, England, 1998).

[26] Alessandrini, G., Bugini, R., Folli, L., Realini, M., Toniolo, L., 'The compositional ratios of mortars. Comparison between chemical and petrographical methods', in: J. Delgado Rodrigues, Fernando Henriques, F. Telmo Jeremias (Eds.), 7th International Congress on Deterioration and Conservation of Stone, Laboratório Nacional de Engenharia Civil, Lisbon, 1992, 667-675.

[27] Alessandrini, G., Dassù, G., Bugini, R., Formica, L., 'The technical examination and conservation of the portal of St. Aquilino's chapel in the Basilica of St. Lorenzo, Milan', Stud. Conserv. 29 (1984) 161-171.

[28] Gutiérrez-Solana, F., Jauregui, M., Bohigas, R., Sarabia, P., 'Analyses of two medieval castles of Cantabria/ Spain' (In Spanish), Mater. Constr. 39 (213) (1989) 37-45.

[29] Hoffmann, P., Vetter, G., 'Analytical examination of mortars from the medieval derelict village Holzeim’, Fresen. J. Anal. Chem. 338 (1990) 133-137.

[30] Lagzdina, S., Sedmalis, U., Bidermanis, L., Liepins, J., Grosvalds, 'Dolomitic lime containing hydraulic additive', Latvian Journal of Chemistry 3 (1995) 93-98.

[31] Vecchio, S., Laginestra, A., Frezza, A., Ferragina, C., 'The use of thermoanalytical techniques in the characterisation of ancient mortars', Thermochim. Acta 227 (1993) 215223.

\section{List of Tables}

Table 1. Average results of x-ray diffraction of different zones.

Table 2. Results of the rapid chemical analysis in original sample of dry mortar. Average values in percentages for the various sampling zones.

Table 3. Representative samples of each class of mortars. Values of soluble fraction $\left(\mathrm{CaCO}_{3}, \mathrm{CaSO}_{4} \cdot 2 \mathrm{H}_{2} \mathrm{O}\right.$ and other compounds of soluble fraction OCSF) and IR (percentages related to original dry mortar).

Table 4. Complete chemical analysis of the complete representative samples.

Table 5. Median and sorting-index.

Table 6. Approximate original composition of the classes of mortars (weight percentages).

\section{List of Figures}

Figure 1. Monument plane. Sampling areas.

Figure 2. Trace elements in representative samples ( $\mu$ g trace element/g dry total sample in percentage).

Figure 3. Results of sample conductivity and anions concentration in representative samples determined by ion chromatography. Conductivity, expressed in $\mu \mathrm{S} . \mathrm{cm}^{-1}$ is given for a suspension of $1 \mathrm{mg}$ of the sample per millilitre; the concentrations of anions are expressed as percentages of the samples.

Figure 4. Aggregate granulometric fractions in representative samples.

Figure 5. TG and DTA curves of MC1.

Figure 6. TG and DTA curves of MC3.

Figure 7. TG and DTA curves of MY1 


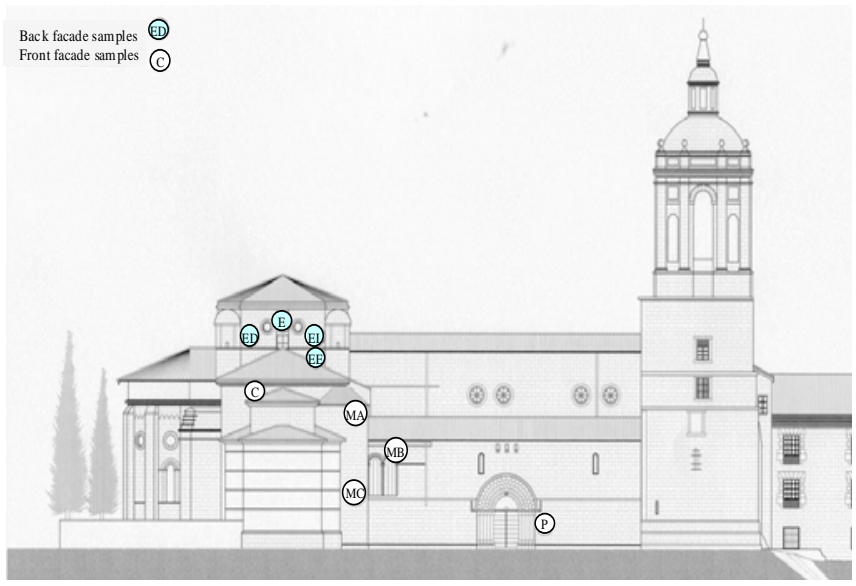

Figure 1. Monument plane. Sampling areas.

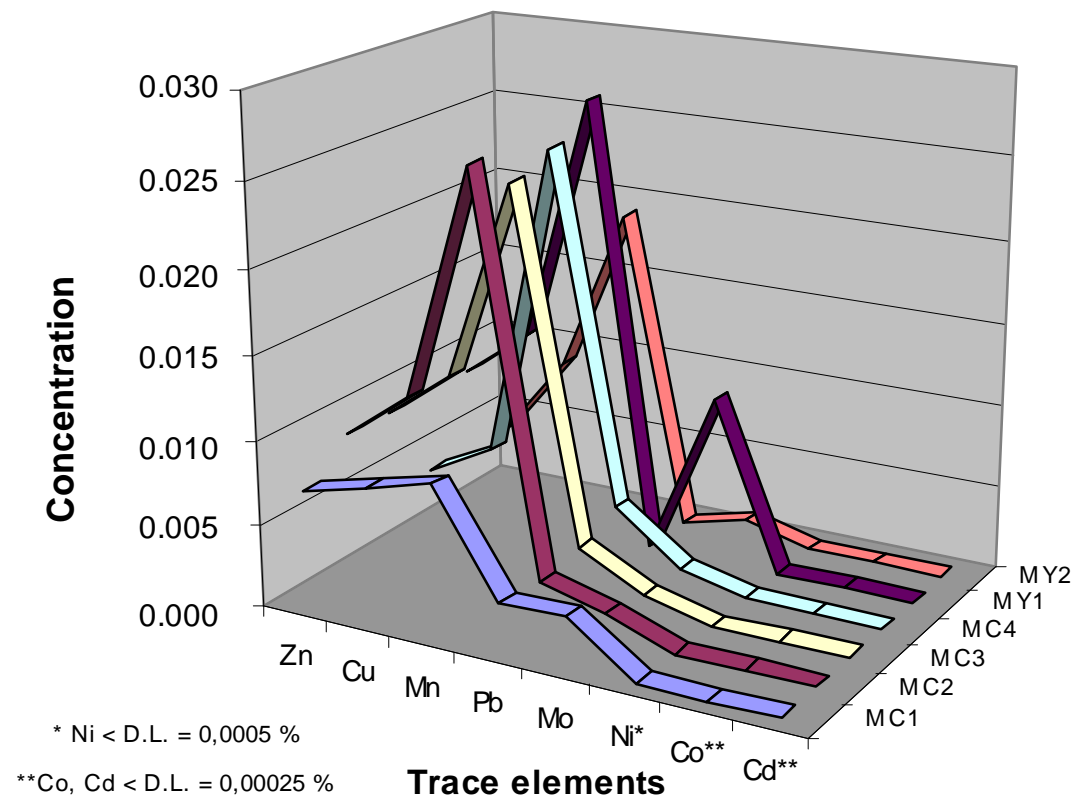

Figure 2. Trace elements in representative samples ( $\mu$ g trace element/g dry total sample in percentage). 


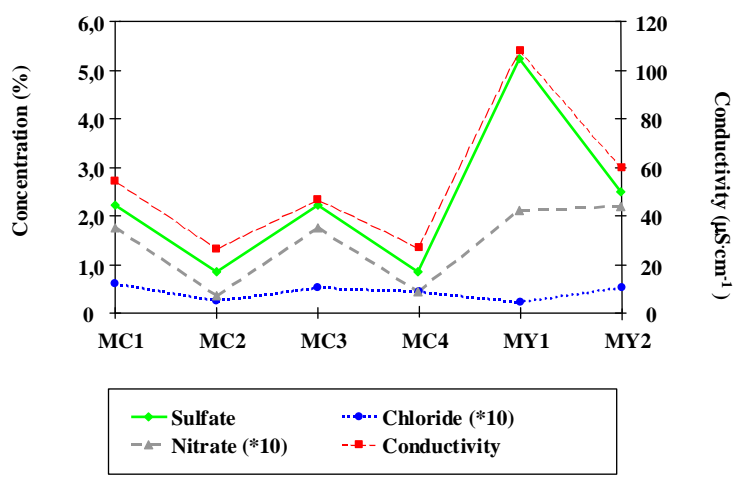

Figure 3. Results of sample conductivity and anions concentration in representative samples determined by ion chromatography. Conductivity, expressed in $\mu \mathrm{S} . \mathrm{cm}^{-1}$ is given for a suspension of $1 \mathrm{mg}$ of the sample per millilitre; the concentrations of anions are expressed as percentages of the samples.

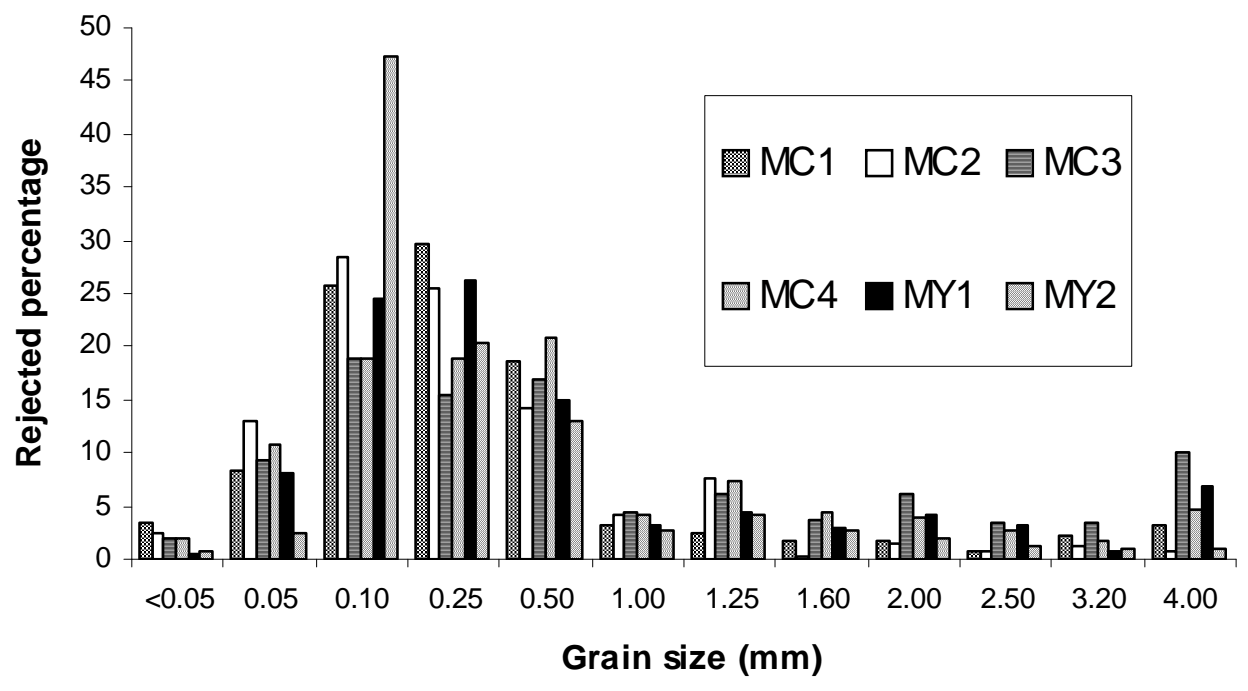

Figure 4. Aggregate granulometric fractions in representative samples. 


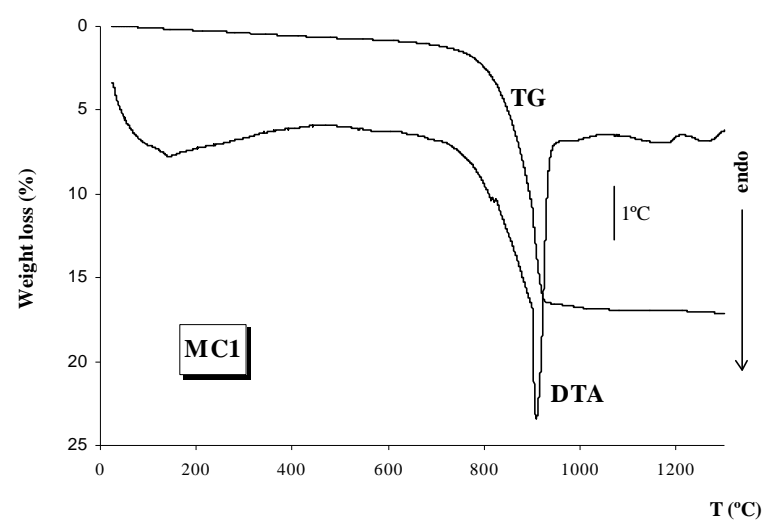

Figure 5. TG and DTA curves of MC1.

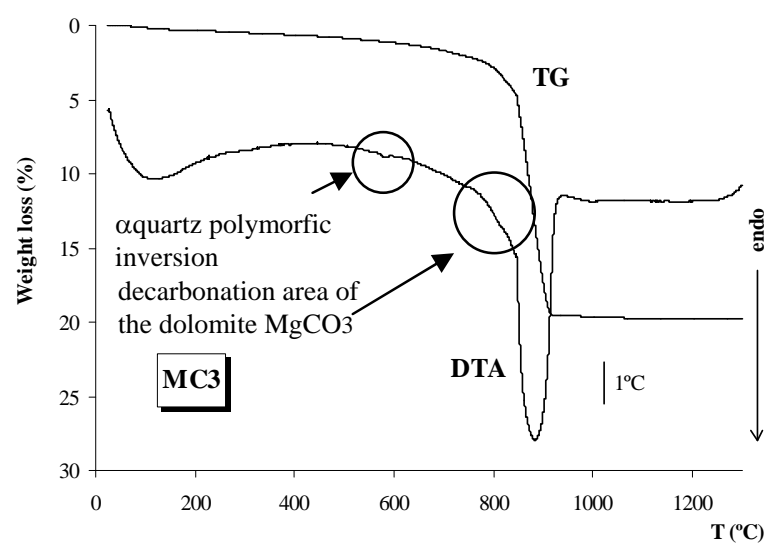

Figure 6. TG and DTA curves of MC3.

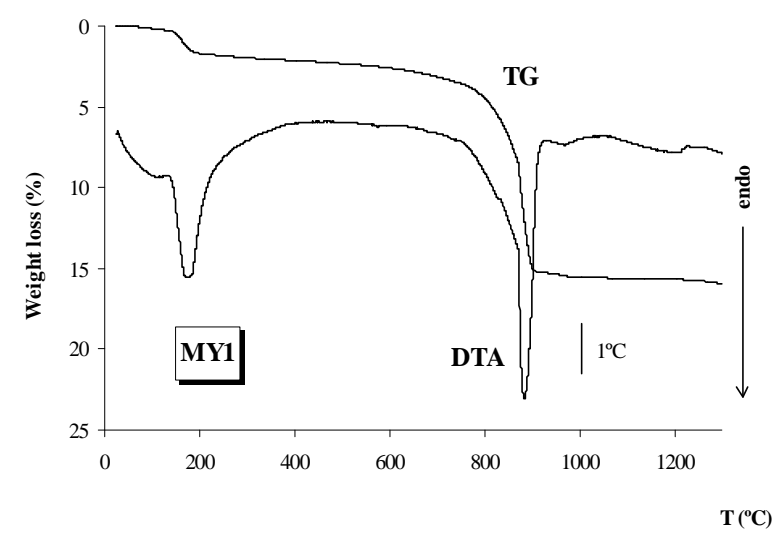

Figure 7. TG and DTA curves of MY1. 